\title{
Reaching Out: \\ Developing Cooperative Programs
}

\author{
Suzanne S. Levy
}

Librarians and archivists exist today in a state of peaceful coexistence, usually in total ignorance of what the other is doing; there is no feeling of mutual purpose and shared experience. In light of their common public - genealogists, historians, and social scientists - it is time that librarians and archivists sit down and share their objectives and expertise in order to develop a common goal of service to patrons. Librarians and archivists can learn from each other and, through sharing, can streamline their processes in preparing materials for public use and thereby give better public service. The computer is an obvious tool to use, and librarians and archivists are already using computer technology to index, catalog, and circulate materials. But the high cost of this technology demands that institutions share the expense, making automation a perfect opportunity for librarians and archivists to work together.

The two must overcome their differences in philosophy and merge the retention and preservation skills of the archivist with the public service, user orientation of the librarian, who understands subject cataloging and excels at finding answers to questions. It is time also to consider merging their pools of bibliographic data into one data base so that a researcher can search that data base or union catalog and know what archival repositories are worth visiting. To do this, archivists and librarians must develop shared subject terms and processing techniques so that their bibliographic data can be merged.

As Richard H. Lytle, in his preface to "Management of Archives and Manuscript Collections for Librarians," states, "The major difference between librarians and archivists is cosmic - a difference in world view. Archivists accept the organizational structure of their resources and interpret their order to users. Libraries impose an order on their materials through comprehensive structures for organization of knowledge." It is

\footnotetext{
Suzanne S. Levy is the Virginia Room Librarian at the Fairfax County Public Library, Fairfax, Virginia. She formerly served as Book Review Editor for North Carolina Libraries.
}

time to overcome these differences and give serious thought to developing cooperative programs for collecting and making available archival information to all. ${ }^{2}$

What public library has not been asked to accept and preserve archival and manuscript materials? According to the Directory of Archives and Manuscript Repositories in the United States, ${ }^{3}$ seven of fifty-one North Carolina manuscript repositories are in public libraries. Thirtythree are in college and university libraries; the remaining eleven are in the hands of historical societies and government agencies. Those public libraries responding to the questionnaire for the directory indicate a primary interest in local history materials; some include genealogical materials, papers, and letters of local businessmen and lawyers. One library specializes in materials relating to Great Smoky Mountains National Park. The college libraries usually collect a wider range of materials to support curricula as well as to preserve the history and records of their institutions. But from the survey, it is obvious that most institutions limit the materials they collect, as indicated in their solicitation statements. This is an important fact when an institution is facing a decision to accept or reject a proffered donation. Will the material fit into the collection development statement of the library or special collection? It must, or the librarian will become inundated with materials for which there is neither room nor staff time to process and preserve. A decision must also be made on whether it is the library's policy to actively seek manuscript or archival materials or to deal only with those which are donated. This too needs to be a part of the collection development policy.

\section{Virginia's Example}

In Northern Virginia, special collections librarians from several types of libraries meet twice a year to discuss on an informal basis how they can collect and preserve all types of materials in a way that shares the work, time, and space restrictions placed on all of them. These 
librarians have collection development statements and are knowledgeable about the statements of their colleagues. When a gift arrives or is offered that one library cannot accept, the librarian knows to whom the item should be referred. Occasionally there will be a gift of such great magnitude that these librarians are compelled to refer the donor to the University of Virginia, the Virginia Historical Society, or the Virginia State Archives. Even though it might go outside the region (the Northern Neck is to Richmond what Murphy and Manteo are to Raleigh, even though the distance is only one hundred miles), the librarians are secure in knowing that they are helping make the material available in the proper setting.

Special collections librarians in the northern Virginia area also work closely with local historical societies and county and city history commissions (appointed by the governing bodies) who frequently coordinate historical activities in their areas. Fairfax County's History Commission, for example, actively uses its collection as a permanent repository for numerous books, archival materials, and ephemera relating to the history of the county and is often able to provide funds for acid-free envelopes and boxes and other supplies, microfilming projects, and even publishing. Commission members provide knowledge of the county and a great deal of advice and guidance on historical matters.

A Local History and Genealogy Section is being developed in the Virginia Library Association. It will provide an opportunity for special collections librarians in all types of libraries to meet and exchange policies and ideas. Once the Section is off to a solid start, its members must contact their archivist colleagues and encourage their involvement in the work of the Section.

Similar approaches can be applied elsewhere. One might start with a college or local government archivist or records manager who can be invited to see the library's operation and share her knowledge with the library staff. An on-going dialogue should be developed to ensure that all parties are providing the public with information, each in her own way but ever mindful of the necessity of sharing the task. Public librarians must also develop a dialogue with their colleagues in the schools in the area. How often do teachers and PTA members come to the public library for historical information on local schools? Often a school has kept very little historical material; public librarians are faced with the necessity of going back to local newspapers and county records of many different agencies, be- cause neither the school board nor the school administrators had the foresight or inclination to preserve dedication programs, newspaper clippings, or PTA records that would provide students and interested adults with important research materials. Schools should be included in discussions on collection development policy and deciding who will keep yearbooks, programs, records, and other necessary archival items.

\section{Uniformity in Subject Terms}

Both librarians and archivists have their particular areas of expertise and should take advantage of each other's knowledge and skills. They can and should work together to gain uniformity in subject terms to make access to information less frustrating for the researcher moving from library to archives and encountering many different subject access points. Attempts by librarians to develop protocols for cataloging manuscripts on-line and by the Society of American Archivists National Information Systems Task Force to develop "a common nomenclature with which to define information systems used in the control of records and the management of records programs"4 are beginning steps in the right direction. SPINDEX, SPINDEX II, SPINDEX III, and NARS A-1 (National Archives and Records Service), PARADIGM (University Archives of the University of Illinois at Urbana-Champaign), SELGEM (Smithsonian Institution), MRMC (Library of Congress Manuscript Division), and ARCHON (Baltimore Regional Institutional Studies Center) are all systems for computer access to archival materials and should be studied for their merits and inadequacies. ${ }^{5}$ Nevertheless, there is still a great need for more interaction between interested parties to find a standard format to describe materials.

Solutions might develop more rapidly if archivists and librarians emerged from similar educational backgrounds. Archivists have largely failed to establish formal educational guidelines, probably because the profession lacks a clearly defined identity. In light of the similar goals of the library and archival professions, it would seem logical to incorporate training pertinent to both fields in a single program. This concept has been convincingly argued in The American Archivist. ${ }^{6}$

\section{Increased Visibility}

Special collections librarians need to be ready, willing, and able to talk up their services and materials to anyone who will listen. One should begin with the reference staff in one's own 
library. They should be familiarized with the collection development policy, special strengths of the special collection, and the willingness of special collections staff to help them achieve their information service goals. Special collections librarians can send memos to other librarians when they add a real find. They can display their materials at any opportunity and write about new acquisitions or old standbys in house organs. A special collections librarian can be her own public relations firm. Eventually the special collections librarian will convince others that she is a major source of information in a given field, and the referrals will come faster than she can handle them.

This increased visibility, of course, brings another problem-how to handle the business that has been generated and, in particular, the mail requests that never stop coming. The special collections department barely has enough staff to keep up with the daily work of acquiring and processing materials and serving the various types of researchers who come in to use the library or archives. One might receive two or three letters a day from researchers all over the country, and a stack can develop very quickly when someone is on vacation, at a meeting, or simply dealing with the annual budget. Since one cannot possibly devote the time needed to adequately answer the questions, one must develop a system for processing them quickly. A librarian at a Shenandoah Valley repository has developed an active corps of volunteers who answer much of her mail using a checklist reply form. The volunteers indicate on the form which sources they have checked and what has or has not been found. In the Fairfax County Public Library, the Virginia Room staff uses a similar form to which is added a list of professional genealogical researchers who use the library and others in the Washington metropolitan area who are willing to do contract work. Library staff members do not spend hours on each request, and searches are limited to checking a few basic specialized indexes that are available only in the collection. The Virginia Room frequently uses volunteers to help with the mail; the volunteers are supervised closely to ensure that they cover all the necessary bases. Volunteers are often able to devote the time to a more thorough search than regular staff would be able to do.

At times, the endless mail requests can be very annoying. Yet there can be wonderful benefits when a letter adds to one's knowledge of a particular subject area, either by providing details on individuals or events that have never been a part of the collection or by leading one to information already in the holdings but never encountered.

To summarize, several things must be done to provide good service at an archives or library manuscript collection. One should have and use a solid collection development statement that everyone in the organization is familiar with. The statement should be shared with librarian/archivist colleagues. Their policies should be known. Librarians and archivists ought to talk with each other regularly so that they can make intelligent referrals and develop cooperation in such areas as subject access, collection development, responsibility for various types of subjects, and applications of new technology. In the era of networking and sharing of resources, communication is an absolute necessary. The service should be publicized so that colleagues as well as the public will use what has been so laboriously processed. This will also lead to new gifts and a strengthening of the collection and its role in both the organization and the community.

Once a dialogue between librarians and archivists has begun, both parties will have to work at keeping lines of communication open. There are great similarities in the two professions, and it is time the skills of both were merged to provide better and more efficient service to the users.

\section{References}

1. Richard H. Lytle, "Preface" to "Management of Archives and Manuscripts Collections for Librarians," Drexel Library Quartery 11 (January 1975): 2.

2. To begin, let us define some terms essential to this discussion. Archives are the records of any institution, public or private, preserved because of their value (Robert H. Bahmer, "Archives, in Encyclopedia of Library and Information Science, ed. Allen Kent, Harold Lancour, and Jay E. Daily, 33 vols. [New York: Marcel Dekker, 1968], 1:515). Private or personal papers are often included in the archival collections of the United States. The term can also be used to describe "an agency or administrative unit responsible for identifying, appraising, accessioning, preserving, arranging, describing, and providing reference service on archives material and for approving the destruction of records of transitory value" (Ibid.). The manuscript collection, often part of modern archives, are those handwritten (typescripts included (materials which can be literary, historical, personal, or organizational in content. They can consist of "letters, memoranda, diaries, business records, drafts, the archives of a family or corporate body, etc. and may include photographs, and some printed materials such as pamphlets, newspaper clippings, and miscellaneous ephemera" (Dellene M. Tweedale, "Manuscript Catalogs and Cataloging," in Encyclopedia of Library and Information Science, 17:119).

3. United States National Historical Publications and Records Commission, Director of Archives and Manuscript Repositories in the United States (Washington: National Archives and Records Service, 1978). 
4. Society of American Archivists National Information Systems Task Force, Data Elements Used in Archives, Manuscript and Records Repository Information Systems: a Dictionary of Standard Terminology (Washington: The Task Force, 1982), 2. 5. H. Thomas Hickerson and Elaine D. Engst, "Archival Applications of the Computer," The Bookmark 39 (Winter 1981): 78-81. 6. Nancy E. Peace and Nancy Fisher Chudacoff, "Archivists and Librarians: A Common Mission, A Common Education," The American Archivist 42 (October 1979): 456-462.

\section{Selected Bibliography}

The American Archivist. Many issues.

"Archives." The Bookmark 39 (Winter 1981): 66-136.

Harris, Lois. "Community Archives: City's 'Trash' May Be Library's Treasure." Focus on Indiana Libraries 36 (December 1982): 3-4.

"Management of Archives and Manuscript Collections for Librarians." Drexel Library Quarterly 11 (January 1975): 1-123.

Mortensen, A. R., and Dorothy Z. Mortensen. The Work of History in Fairfax County: an Appraisal and Recommendatioms. Fairfax: Fairfax County Historical Commission, 1971.

Thompson, Enid T. Local History Collections: a Manual for Librarians. Nashville: American Association for State and Local History, 1978.

U. S. National Historical Publications and Records Commission. Directory of Archives and Manuscript Repositories in the United States. Washington: National Archives and Records Service, 1978.

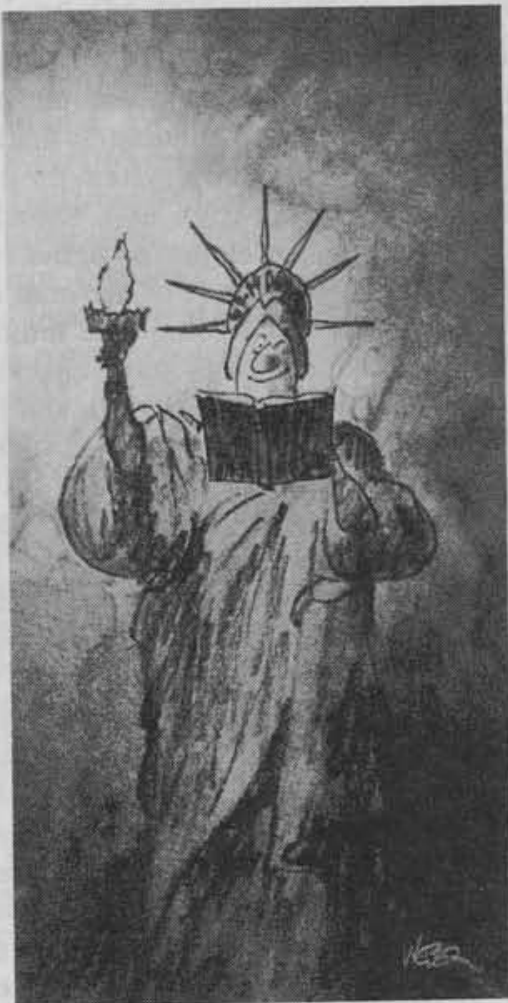

Free your mind. Use your library.

American Library Association 


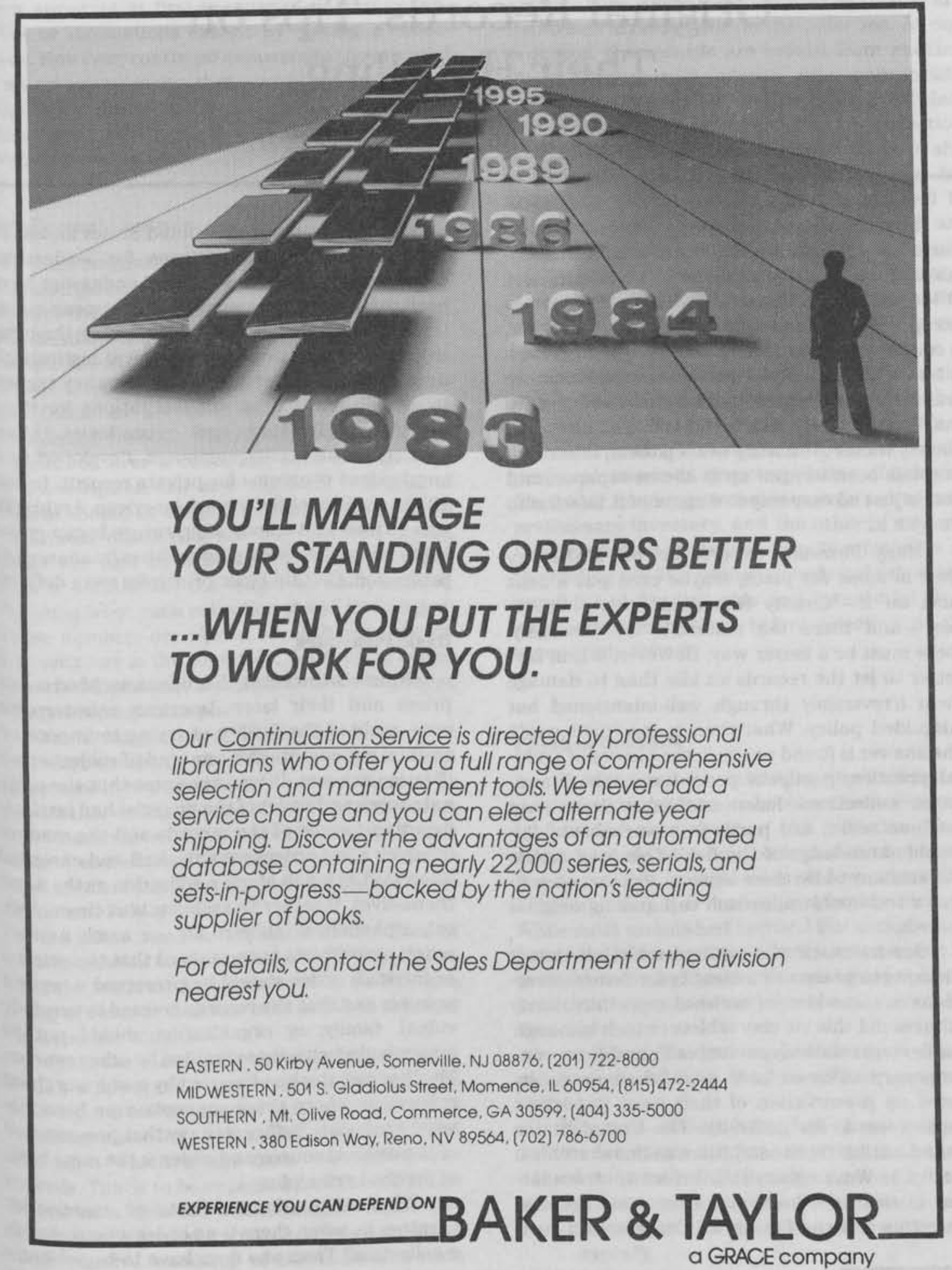

